\title{
SUBSTANTIAL AND SUBSTANTIVE CORPOREALITY IN THE BODY DISCOURSES OF BHAKTI POETS
}

\author{
YADAV SUMATI* \\ PG Govt. College for Girls, Chandigarh, India
}

\begin{abstract}
This paper studies the representation of human corporeal reality in the discourses of selected Bhakti poets of the late medieval period in India. Considering the historical background of the Bhakti movement and contemporary cultural milieu in which these mystic poets lived, their unique appropriation of the ancient concept of body is reviewed as revolutionary. The focus of the study is the Kabir Bijak, Surdas's Vinay-Patrika, and Tulsidas's VinayPatrika, wherein they look at and beyond the organic corporeality and encounter human body not as a socially, religiously, economically stamped noble body or lowly body; male body or female body, but a human body. This paper explores how, like existential phenomenologists, these poet/singers decode the material reality of human beings and link it to the highest goal of achieving Moksha (liberation from the cycle of birth-death) by making body a vulnerable but essential instrument towards spiritual awakening. The paper also reflects upon how these poets have suggested a middle path of absolute devotion to God while performing all earthly duties, seek spiritual enlightenment and avoid the extremities of asceticism and hedonism.
\end{abstract}

KEYWORDS: corporeality, body, liberation, salvation, bhakti

In this Kali Yug the body is full of woe, care, wickedness and diverse pains. Where there is steadfastness, peace and all purity, rise, Kabir, and meet it there.

(Kabir)

Those powerful rulers who had conquered the whole world, even made Yamraj (the God of death)

their captive and tied him up-even they became the food of Kaal (Time), what do you count then? Contemplate and think about the whole matter seriously yourself-what is the truth, what is the reality. (Tulsidas)

One piece of iron is kept as an image in the temple; another forms the knife of a butcher The Philosopher's stone does know such distinctions; turns them in pure gold One is called a filthy runnel, another a river When meet, become alike and are called the holy Ganges.

(Surdas)

* YADAV SUMATI (PhD 2006, Indian Institute of Technology, Roorkee, India) is Assistant Professor in the Department of English at PG Govt. College for Girls, Chandigarh, India. E-mail: sumati05@gmail.com. 


\section{Introduction}

Human corporeality has always been the part of the Eastern and Western religious/ philosophical/ cultural discourse both in the Western and Eastern ancient world views to the modern debates on the diverse appropriations of body. Being human entails a plethora of questions of meaning, relevance, role, responsibility and possibilities and therefore it has been significantly investigated, discussed and interpreted in scriptural exegeses, social sciences, humanities and scientific studies alike. Although, these questions have still not been fully answered, or the answers have still not been unanimously agreed upon but the interaction of ideas from one discursive context to another has kept the debate open. Such reflective attitude seems more relevant now than forever, when in the wake of the Fourth Revolution, humanity is again face to face with a new set of existential questions.

Interestingly, despite being subject to the divergent cultural categorizations, the perceptions regarding body seem to have convergently evolved among all spiritual traditions. In the ancient Vedic and post Vedic Hindu traditions, treatises were written on human physicality cum physiology besides philosophical commentaries situating it in the whole scheme of things: Ayurveda Shashtra's two Samhita (Compendium) namely, Charak Samhita and Shushrut Samhita examine and explain human anatomy and physiology; Samudrika Shashtra is an exposition on the whole body examination including face reading and palmistry; Various texts on yoga such as written by Dattatreya and Patanjali present a system of physical exercises which lead to a meditative state, which in turn help achieve spiritual freedom or liberation; Kamasutra by Vatsyayan centres on using the body for emotional fulfilment and Devalaya Vastu in the Agama literature prescribes the temple architecture based on the structure of human body. These are just a few major titles which are representative of the category that looks into the various interactive organ systems within a human body and the resultant physiological states.

Besides, when it comes to comprehensively looking at life; its cause, purpose, nature has stimulated thinkers from ancient times till date and forced their musings to extend beyond the physical realm and towards the metaphysical one. Hindu philosophy, which is an umbrella term for six orthodox philosophical systems (Nyaya, Vaishesik, Sankhya, Yoga, Mimansa, Vedant), underlines the two primal essences of the universe, i.e. Prakriti (nature/ matter) and Purusha/Brahm/Parmatma (Supreme soul or consciousness/Absolute reality). Although these systems do not necessarily agree on how and to what extent Nature is informed by Supreme Consciousness in the framework of creation but all of them agree on one premise that the individual self or soul or spiritual reality of life is never 
essentially a corporeal reality which includes the biological, physical and psychological aspect of what is understood as human life; it gets to reside in corporeality due to ignorance or past Karma and can get salvation only by attaining the knowledge of its reality. Body as a dynamic factor in facilitating salvation was not paid much attention to.

This path of knowledge gave precedence to evolving the spiritual power through asceticism and rigid physical practises. It was restricted only to a few knowledge and yoga practitioners. Holdrege rightly says that the upanisadic sages locate the source of bondage in the embodied self's attachment to the material psychophysical complex and consequent failure to recognise its true identity as Brahman-Atman which in its essential nature is unmanifest, nonchanging, unbounded and beyond all forms of embodiment. In this context, the human body is often ascribed negative valences, becoming associated with ignorance, attachment, desire, impurity, vices, disease, suffering, death and salvation was contingent upon gyan marg (acquiring wisdom through scriptural reading), karma marg (performing duties with detachment), bhakti marg (complete surrender and engagement with recitation of and meditating upon God's name) and asceticism, with a 'regiment of practices' as a 'means of overcoming all forms of embodiment' (Holdrege 2015: 18).

Notably, the ideology of this movement was set against the backdrop of a feudalistic society of Medieval India with a rigid Nasl (Race), Varna (Social class), Bhasha (language) and intricate Jati (Caste) system in which people at the lower strata of economy and society were generally deprived and devoid of any relatable philosophical, religious or moral progress. Moreover, the dry, abstract and complex intellectualism of the Gyan Marg was incomprehensible to them and rendered them vulnerable at the hands of a few at the top of the knowledge hierarchy, i.e. the Brahmins, the highest class. Meenakshi Khanna notices in Cultural History of Medieval India that,

In brahminical normative texts as well as in non-brahminical sources, a community was never defined in terms of religion alone. The Hindus affirmed identity and marked exclusion in other ways: for example, by referring to doctrinal belief by terms such as Boddha, srivaishnava, pashupata; or those who adopted specific practices such as kapalika (skull-bearer), kanphata (split ear); to family descent such as yadava, suryavamsi; or to caste groups like brahmana, khatri; or to ethnicity as in yavana, mlechha and so on. Individuals or groups were used to being referred to by more than one such designation at the same time. In other words, Hindus traditionally functioned in terms of multi-layered identities, reflecting the complex relationship between socially diverse groups (Khanna 2007: xvi).

In fact, this identity taxonomy invariably had body in the foreground, invested and infused with the corresponding attributes so much so that the 
generic space of common corporeality was annexed by such systematic attributes. The presence of such classification implies discrimination which culminates in subjugation led exploitation and humiliation. In this scheme of things the souls embodied as a shudra or atishudra (the lowest and the lowest of the low. untouchables) could never be salvaged. Prized corporeality was perpetually pitted against the cursed one both in theory as well as in practice: the pure body versus the polluted one. On the basis of a collective study of various Hindu discourses, Barbara A. Holdrege also talks about 'a multileveled hierarchy of bodies interconnected through a complex network of transactions' (Holdrege: 1998, 370).

Consequently, for certain disadvantageously designated social bodies, practicing and following either of these paths was unthinkable: either they were ignorant of the world of spiritual possibilities or they dared not infiltrate the hallowed territory of scriptural knowledge, or burdened with the problematic of social and economic survival, earthly duties and lack of empathetic guidance disabled their orientation towards complete devotion to an unmanifest God of an aniconic tradition. Even among them, those who worshiped the localised, iconic divinities were either fearful/ill-fated or grateful/blessed bodies who approached them indirectly through rituals for physical sustenance; emotional devotional engagement of these bodies was uncalled for. In this manner, the religious and social practice of Othering the bodies rendered the concept of universal human corporeality with universal spirituality redundant and ironic for those who believed the essential realities of scriptural wisdom. This lack of both equity and equality for the deprived bodies by the intolerably proud and privileged bodies gradually brewed into an intensified existential tension which just needed a nudge to unsettle the whole complex network of differently situated, wideranged human corporeality.

From the 7th century onwards, that nudge indeed came in the form of a major turn in the salvation theory came in the form of the Bhakti (devotional) tradition of the Vaishnav saints, Alavars and Saiva saints, Nayanar in south India who rejected the concept of Nirguna Brahm (the formless, attribute-less Supreme Divine) and introduced the authority of the Saguna Brahm (the Supreme Divine with form and attributes; either Vishnu or Shiva or Shakti). Acharya Ramanuj spread Vaishnavism as an allinclusive tradition with its main focus on disseminating the idea of Bhakti, irrespective of caste and class. His disciple Ramanand took the movement to North India and gradually it spread all over the Indian Territory. All Bhakti poets basically drew the idea of body, soul and salvation from Vedic tradition but democratized and localized the path to salvation. Jayaram V. Says of the Vedic concept of Bhakti; 'Devotion is considered the most excellent path of liberation. However, everyone cannot practice it since it 
requires a lot of discipline and purity' (Jayaram, www.hinduwebsite.com). The Bhakti movement gave rise to a post-Vedic revolutionized idea of Bhakti: it was transformed from mere worshiping and devotion to intense devotional attachment to God for attaining salvation. The popularity of the later generation devotee-poets like Kabir, Raidas, Surdas, Mirabai, Chaitanya Mahaprabhu, Tulsidas, Namdev can be attributed to their preaching and practicing the idea of the essential constitutive and functional similarity of human materiality, rejecting class, caste, gender, language and ritualistic barriers.

This article takes for analysis three texts written by three dissimilarly similar Bhakti poets Kabir (15th century), Surdas (16th century) and Tulsidas (16th century) respectively: Kabir Bijak, Sur Vinaya Patrika and Tulsi Vinay Patrika. These poet/singers have left a very valuable oral or written body of rhetorical discourses behind wherein they have dealt and responded to the problematic of human existence: in its structural, phenomenal and functional conditions. By engaging with their inner selves they have tried to find out the marm or saar (truth, substance) of human life experienced on this earth and its relation with the cosmic reality. The article gleans their ideas on the corporeal existence of man in all its basic and extended meanings. It examines how they necessitate the connection of the bodily reality with the spiritual reality by way of Bhakti for what Modern psychologists call Well-being. It critiques their ideas which caused major shifts in the bodily identities from ascribed and inscribed reality to avowed or subscribed reality in the Bhakti Kal (Medieval India). It also tries to explore whether these discourses the tremors of which were strongly felt in India even in later centuries and forced an inclusivist attitude in society, can again salvage an cognitively modern humanity which is rife with the more dangerous revisiting bigotry, hedonism, increasing intolerance, open display of hatred to name just a few.

The Bhakti movement is recognized as a 'Hindu revivalist movement' and 'the silent revolution in society brought about by a galaxy of socioreligious reformers' (see knowindia.gov.in). The Bhakti Poets repudiated the severity of orthodox Hindu religious and social customs, and their discourse of equality cut across all religious, social, economic and geographical boundaries.

\section{The Twist: A New Body Discourse}

Bhakti means 'attachment, devotion, fondness for, devotion to, trust, homage, worship, piety, faith or love or devotion (as a religious principle or means of salvation, together with [karman], "works", and [jñana] "spiritual knowledge"' (Williams-Monier). The idea of the embodiment of soul serves as the point of both departure and reference for the Bhakti poets in their 
reflections on body. Their poetry serves as a template for hermeneutic phenomenology providing the interpretation of the nature of being, living and doing 'through the symbolic apparatus of the culture' (hermeneutic phenomenology, www.phenomenologyonline.com). All Bhakti poets acknowledge the kinship of the soul to the Supreme Divine and envision salvation through a constant Bhakti Bhav (devotional attachment) to a single God. The Corporeal reality; Body is called as Deh, Sharir, Tan and it is a three pronged entity consisting of the Sthul sharir (gross body), Suksham sharir (subtle/mental body) and Karan sharir (causal body). It is roughly composed of the five gross basic elements, invested with the differently combined three Guna (attributes), sense organs of action and perception, mind, intellect, ego and conscience. The gross and subtle bodies perish after death but the causal body which consists of Sanchit karma, i.e. the balance of acquired karma of previous births, remain attached to the soul when it departs from the body. The next embodiment of the soul depends on the tendencies inherent in the causal body. This cycle of birth and death continues until the residual karma get exhausted which is contingent upon developing satvik tendencies and detachment thereby. Let us now consider where and how this body figures in these poets' world view as it is represented in their devotional song poetry.

These Bhakti poets/singers have addressed the problematics of the human reality in a humanistic manner which reminds one of the Western Humanistic psychologists like Abraham Maslow and Carl Rogers, and Existential phenomenologists like Martin Heidegger, Maurice MerleauPonty and Jean Paul Sartre. However, the commonality of their approach with the Existential phenomenologists goes as far as human existence is unlayered of various attributes and penetrated to its core, and human experience is considered embodied. The Bhakti poets'/singers' unique approach to existence and phenomenon is based on three major premises, i.e. (a) human beings are souls embodied, not mind or consciousness. (b) Human life is invested with a purpose, i.e. of seeking permanent bliss through spiritual liberation (c) human souls have the freedom and chance to get released from physical entrapment (salvation) only by experiencing physicality. Their standpoint lies at the intersection of Hussrel's disembodied consciousness, Heidegger's concept of Dasein (being there) and Merleau Ponty's theory of embodied or lived experience. It takes a detour from there. These poets have treated human body and its experiences with a sharp insight of a phenomenologist who penetrates its phenomenal reality, sees a noumenal reality beyond and link the both to construct a higher reality of a life with a purpose. Instead of seeing body as an arbitrary object/subject phenomenon, punishment or an evil necessity, they see it as a prized opportunity invested with the potential for everlasting freedom and 
bliss. Adopting a holistic approach, these poets exhort man to treat the body as an opportunity for self (soul)-actualization. Keeping the context of their discourses, they are closer to the Humanistic psychologists in their schema of self-actualization, albeit with a contextual twist.

Looking at life, being born as a human being is emphatically declared to be Anmol (invaluable) and Durlabh (rare) privilege which is not available frequently. Compared to other life forms, human have an added advantage of having the discerning power; Buddhi (Intellect) to guide us through the deceptive terrains in the course of life. Although life in this world is said to be transient and ever-changing, it is a real and crucial stage to pass through in the soul's journey towards its ultimate station: at home with the Supreme Soul or God by attaining Moksha.

The Bhakti movement, with a mixed range of devotee poets/singers mobilized the psyche of the masses, most of who belonged to the lower rung of the society, towards a positive reconstruction of the body reality. Either by way of mockery of the feudal/brahmanical system or by way of devotional surrender to God, they acknowledged and emphasised the universal substantial/elemental transience of the organic corporeity.

Their exhorting emphasis on the fundamental uniformity of the form (anatomy), function (physiology), meaning (spirituality) of human beings and on the naturally available scope for each and every embodied soul to positively engage their bodies on the journey to salvation gave rise to a new body discourse wherein body became that prized possession which the soul necessarily needs. The zealous reception of this melodious form of discourse served twofold purposes: They highlighted human body as rare opportunity to salvage the self, not to undermine and begrudge it. By repudiating the extremities of asceticism and hedonism and introducing Bhakti as a middle path and thereby facilitating both performance of earthly duties and complete surrender to God, they opened a healthy dialogue between the soul and body wherein the soul needs to utilize the crude human corporeality, bereft of the artificial attributes of the web of normative identities. Moreover, such a discourse made the whole body dynamically involved in the performative task of Bhakti: instrumental in singing Bhajan (devotional songs), dancing and meditation in action.

\section{On Substantial Corporeality: Gross perishable human body-Kabir}

The idea of body in Kabir, though basically drawn from the Vedic traditions, gets modified and illustrated through various similes and metaphors drawn from the everyday life of a common man. Although these three poets have used Regional dialect for disseminating their deeply spiritual discourses yet the content of Kabir's songs is more and diversely localised than the other two. What Ajai Kumar Chhawchharia says about 
Tulsidas regarding his rhetorical style goes undoubtedly for Kabir and Surdas as well: 'As we move along charmed by the wonderful text of Vinai Patrika, we come across splendidly narrated and most apt metaphors, similes, analogies, aphorisms and parables, some interwoven in the verses so as to mingle with them almost imperceptibly, and some others standing out with entire verses devoted to them' (Preface).

Kabir employs the mundane-world metaphors to convey the perishability of gross human body and calls it a Panch tatva ka putla (an effigy made up of five elements), mandir lakh $k a$ (a temple made of lac), das dware ka dehra (a temple with ten doors, the dwelling place of the divine spark), bohat (ship), kachha ghada (unbaked earthen pitcher), bulbula (water bubble), kagaj ki pudiya (paper packet) consisting dust, kanchali (slough of snake), beda jarjara nav (dilapidated ship), ban (forest) cut by karma, semal phool (silk cotton flower) and Kathi (saddle) being eaten by termites of time. He compares it to a holy Indian city, Kashi, which is believed to ensure moksha for anybody who dies there. He also calls it a water bubble and a broken boat. The essential transience of the body is explicitly put across in another couplet:

Gorakh was in love with his devotions: he would not allow his dead body to be burned. Yet his flesh decayed and mingled with the dust, though his body gleamed with much rubbing (Shah: 1917).

Sometimes, the corporeal transience seems to have been thrusted upon those who rigidly identify the perceptible bodies through marks, signs and various denominations may be to jolt them out of their illusionary pride. Dead, what will you do with your body? The soul departs, at once it is cast forth. [...] When the corpse is thus forsaken, it meets varied usage: some burn, some bury it in earth (Shah: 1917).

He also reflects that 'To this figure of five elements the name of man is given' and that 'This body will be mingled with the earth, as the salt in the flour.' The powerful working of the dynamics of both Time and Death on the body is unhesitatingly presented in the following lines: The body is wood and Kal a weevil/ he devours in various ways/ Kal has settled within the body/: no one reads the secret./ Today, tomorrow, or any day comes death: the body is not lasting./ How many days, O man, can you keep water in an unbaked vessel? (Shah 1917)

\section{Surdas}

Surdas also considers the human body as a blessing and a reward for the good deeds done in the previous life. He represents body as the soul's dwelling place which is infected by the five Vikar (vices/evils/weaknesses): Kaam (lust), Krodh (anger), Lobh (greed), Moha (attachment) and Mad/Ahankar (conceit). Moreover, the mind, yoked to the material 
pleasures, delays the soul's salvation. In him, we come across a body which, if devoid of the purgative power of Prabhunaam (God's name), keeps the soul bound within the boundaries of skin for ages. He also compares it to a cage, a field, a ship stuck in the whirlwind of desire-ridden feelings, a house and water bubble. The transient body ends up either as ashes or worms or excretion:

teenan mai tan krimi, kai vishtha, kai vha khak udei surdas bhagwant bhajan binu, birtha su janam gavaih/

Surdas has wasted his birth as human without devotional meditation on God (Singh 2016, verse 92).

He also urges the Self not to waste this Kshanbhangur (transient) bodily platform which is getting wasted like a handful of water leaking incessantly. It is only through the medium of body only that the Self can traverse the ocean like worldly existence. Surdas calls body Tan-taruvar (tree-like body) which, when falls down loses the pride of place in the world. So making the best of this gift from God to break free from the life cycles' bondages is repeatedly stressed upon as according to him, manush janam naam narhari ko, mile na barambaar (human form and the privilege of reciting the name of God is not given again and again), ghatei pal pal badhe chin chin, jat lagi na bar (as the body grows every moment, the number of years left decreases, it doesn't take much time to go) and Surdas kuch thir na rahego, jo aayo so jato (Surdas nothing will survive, whatever comes, will go) (Singh 2016, verses 90, 93, 103).

Moreover, he reprimands the Self for not valuing this precious gem of human life by not carefully utilizing the jewel of human body. He earnestly prays to God to mark him as his own so that he can live a disciplined devotee's life in the human body 'village'. His is a self (soul) proclaimed fallen, degenerate body which can only be revived by God's grace to help the soul realize its own, spiritual self. He also considers human physical form to be constrained by time and deteriorating irreversibly through the four stages of childhood, adolescence, adulthood and old like a handful of water recedes despite holding it carefully.

\section{Tulsidas}

Tulsidas, in his Vinaya Patrika mentions human body as a microcosm of the universe wherein the jiva (self) resides, surrounded by all demonic tendencies and evil desire borne sufferings:

This body is made of seven elementary constituents ('saptadhātu-niramita tanu kariya bicāra'-blood, lymph, flesh, muscles, bones, sperms and mucous). The only object and purpose of acquiring or receiving this body, the only fruitful use 
of this human body is to be benevolent, beneficent, compassionate, merciful, helpful and kind to others (tēhi tanu kèra èka phala, kījai para-upakāra) (Chhawchharia 2017, verse 203).

He declares that as the body is subject to the cycle of birth and death corresponding to the fruits of the souls deed in a lifetime, it is "infested with worms and maggots, when smite, flies and insects will feed on it, and when it would be cast to the dump in mud, ash, filth and faecal matters upon your death' (krmi-bhasma-bita-parināma tanu). He knows the body to be transient so if it perishes without ensuring salvation to soul, he would consider it to be wasted, not utilized. 'Alas! Your life is decaying and going to waste by the passage of each moment (china-china chinna hōta jīvana); you have already wasted this rare human body (in futile worldly pursuitsduralabha tanu brthā gam்̌̃ $\bar{y} \bar{o})$... The death-like serpent is consistently eating away at this mundane, temporal world (kāla-uraga jaga khāyō)' (Chhawchharia 2017: 136, 199).

Through the following verse, he admonishes the soul for its compulsive arrogance and pride in possessing a beautifully moulded body:

Oh Creature! It appears that you (are proud that you) have got a body cast in copper (or, a body which is as valuable, strong, long-lasting and rust or disease free as a new vessel made of copper-'tāmbè sō pīthi manahum tana pāyō')! [...] Oh you wicked and an exceedingly foolish one (nīca)! You do not know that death is dangling like a sword (literally, dancing) on your head (mīca jānata na sīsa para) (Chhawchharia 2017, verse 200).

The body is pictured as being the rarest, evolved and privileged form (ati durlabh tan) among all living beings and having relational interactions with the other animate/inanimate, sentient/non-sentient beings while being subject to the the following threefold sufferings (Traitaps): 'Adibhautik, Adhyatmik, Adidaivik. These respectively relate to the sufferings caused (i) by the physical world and its inhabitants, (ii) from spiritual causes, and (iii) maligned stars and unfavourable gods and forces of Nature' (Chhawchharia 2017, verse 73). Therefore, human body is an opportunity that shall pass.

Tulsidas projects the world to be a treacherous forest which the embodied soul has to pass through with the constantly impending fear of the susceptibility of the body to guile of illusion. Like Kabir, Tulsidas also calls it a karma gifted old, triangular cot bearing the self and being carried by the drunken carriers on the uneven path of this worldly life. Markedly, mind- the cognitive aspect of human corporeality has been held responsible for blinding the soul's vision of reality and tricking it into engaging its physical properties for material pleasures instead of the spiritual pleasure of knowing itself. 


\section{Substantive Corporeality: Spirituality Conditional upon Corporeality-Kabir}

Kabir became the pioneer of the reformist movement which merged the dividing hierarchical lines between biological, social, religious and spiritual aspects of human existence. As he firmly believed that the immortal soul (as a fraction of the Supreme Soul) 'dwells' in every body to utilize its amazing potentialities, it is irrespective of the non-natural identity marks and labels of a body. So, in mocking and rejecting them, he brought the idea of salvation from a high pedestal down to an earthly level where it could be shared and aspired by all. It was like the 'clear formatting tab' on an MS Word page in a computer which says 'clear all the formatting from the selection, leaving only the plain text.'

He calls human body durlabh (rare), anmol (invaluable), das dware ka dehra (a temple with ten doors, the dwelling place of the divine spark) and akin to the holy Indian city, Kashi which is supposed to ensure salvation for those dying there. He also suggests: Hari kirpa tab janiye, de manav avatar (consider it to be the grace of God that gave you human birth, see Shah: 2016).

However, he also acknowledges that soul is deluded by Maya (the natural power of illusion) into identifying with the material body of the material world, and that the unstable mind manipulates the soul into believing the physical desires to be its own. Astounded by the eager body's actions and their pleasing fruits, the illuded soul starts having attributes which hinder from it path to freedom. Kabir scolds the embodied soul and asks it to set its house in order by not indulging with the worldly pleasures guileful ways and thereby be doomed forever:

What sense is pride of wealth or body: $\mathrm{O}$ mind distraught ?

These are a prize for earth and earthworms: Know this, $\mathrm{O}$ mind distraught.

[...] Within these five elements is the abode of that which is hidden.

There are but few who find the secret. The Guru's word is the proof.

[...] Within the heart is a mirror, yet the face cannot be seen.

[...] The soul has perished by reason of the tongue: every moment they speak unworthy words (Shah 2016).

He reminds the soul about its relation to the God and the imminent death of the physical form 'Hari is a flame and you a moth: Yama has made his abode with the soul' (Shah 1917). Therefore, the soul has to fight like a warrior within this form, slay the enemy senses that are kusangi (bad companions) and subdue the 'self-crowned king'-the mind into stability. Then freed from excessive desire borne feelings cum diseases, 'the true soul will not die' (Shah 2016). 
He wants the soul to hurry for ridding itself from the earthly attachments because the physical life span is subject to decay and death:

By reason of the mind they go astray in error and Kal swings them hither and thither.

The mind is a sea, and desire is the wave: many are swept away and drowned.

[...] Those who did not reach the shore when living, how can they cross when dead, who did not cross when living? (Shah 2016: 194)

Remarkably, human corporeality finds the place of pride in these poets' scheme of salvation. The whole body, in deeds, thoughts and actions, immerses itself in a loving devotion to the attribute less absolute God and thereby facilitates the permanent bliss for the soul. Kabir asserts:

In this body I taught the means whereby the ruby is attained:

in many ways the mind was perverted (Shah 1917).

[...] Even ill company leaves no stain on him, whose hand clasps the ruby of wisdom.

Just as a juggler's boy plays fearlessly with a snake.

[...] Trust your own hands, your arms, your strength: give up reliance upon others.

When through his courtyard flows a river, how can he die of thirst?

[...] O Kabir, who grasped not Rama's protection, at the last grieved sore.

While in the world, keep fixed your roving mind, and your gaze unwavering.

As you ever see trouble now, so will happiness ever be yours hereafter (Shah 2016).

According to Kabir, the soul needs to control the senses and steer them to grow satvik guna (attribute of purity through love, empathy, brotherhood, equality, equanimity) while meditating on God's name, and stop generating karma. Consequently, by developing the power of discernment (a corporeal constant), the soul can escape because then, it will know the truth of its relation to God and will escape further earthly bindings filling the heart with His love, as without it 'in the void, the all-they have lost themselves...', 'then only will the face be seen, when doubt has vanished from the heart. $\mathrm{O}$ Kabir, deck thyself in the garments of love, and dance' (Shah 2016).

For who practice such devotional love to God, Kabir claims, 'The men of Hari in the form of Swans (souls) range far and wide: they gather up the holy name and chant it. They bear in their beaks the wreath of salvation and charm others with it: they keep silence or else they sing the praises of Hari' (Shah: 2016).

Leaving the worldly relations beyond on the other side of the threshold, soul swan keeps the body bier at the burning place and then goes alone to 
its master: 'Will any lover of Ram drink his wine? If one drinks he will live in bliss' (Shah: 2016).

\section{Surdas}

Surdas considers human body as a blessing and a reward for the good deeds done in the previous life. For him, it is like a precious gem gifted by God. It is soul's dwelling place and is better than all life forms owing to its possession of intellect. An embodied human soul is a pargami; capable of sailing across the material world. For him, making the best of this blessing to break free from the life cycles' bondages is repeatedly stressed upon. He says that this physical form has been bestowed upon the soul to develop the virtues of divine love and detachment and not get oblivious of its reality in the gross world made fascinated by Illusion. He reprimands his soul for not knowing the proper utilization of this gift of God like a monkey doesn't know how to use the coconut and plays with it. He also warns the soul repeatedly about the impending death which will take it away before it wakes up from worldly slumber of a degenerate but still desiring body. It will depart with regret then. He believes that Prabhu naam (recitation of God's name) will cure the soul infected by panch vicar (five evils/vices): Kaam (lust), Krodh (anger), Lobha (greed), Moha (attachment) and Mad/Ahankar (ego, conceit).

Surdas is a staunch devotee of Lord Krishna; God in His Attributed form. He acknowledged the bio-physiological barriers to salvation but at the same time, also acknowledges that without the full participation and support of the body, the soul will keep entangled in the processes of birth, death and transmigration:

man bach krum jo bhaji shyam ko chari padarath det (if God's name is recited with personalized devotion, he fulfills the four desired goals of human beings that consist of prosperity, pleasure, righteousness and spiritual liberation) (Singh 2016, verse 98, translation mine).

Such intense devotion to God will end the cycle of birth and death for the soul so instead of letting the sense and mind wander unsatisfactorily into the quagmire of worldly objects, they should be withdrawn unto themselves so as to experience the real, permanent pleasure. It will only after giving up the material obsessions that the body will also feel the overwhelming bliss: vishya jat, harshyo gaat (absence of gross pleasures elates the body) (Singh: 2016, verse 283). In fact, Surdas seems to mock the soul for its ignorance of its reality. He likens it to the musk deer that wanders madly in search of the musk which remains inside his body and gets to the reality only by employing the senses inwardly. 
And like other Bhakti poets, he also find an intensely loving devotion to God to be the ultimate path to spiritual liberation because:

Badi hai ram nam ki ot

Saran gaye prabhu kadh det nahi, karat kripa ko kot

Baithat sabai sabha hari ju ki, koun bado ko chhot

Surdas paras ke parase mitat loh ki khot (Great is the shelter of god, he doesn't banish but bestows his grace, everyone is equal in his court, like a Philosopher's stone, his presence rids us of our impurities also) (Singh 2016, verse 141).

\section{Tulsidas}

Ajai Kumar Chhawchharia briefs how Tulsidas's idea of the corporeal body and its potential reflects the corresponding ideas in the Upanishad like Sharirikopanishad and Prashanopanishad. According to them the constitution of the body is like this:

The earth element formed the solid part of the body, the water element formed the fluid part, the fire element formed the warmth and heat of the body, the movement of the body is revelation of the air element, and the subtle space between various organs and tissues of the body, both at the external as well as internal levels, is the sky element. The next level would the various Koshas or Sheaths that are made of a combination of these five elements.-Anna Maye Kosh (the food sheath), Pran Maye Kosh (the vital wind sheath), Manomaye Kosh (the mind sheath), Vigyan Maye Kosh (the intellect sheath), and Anand Maye Kosh (the bliss sheath)... like the elements or units that decide the complexities of the creature's body and its position in the hierarchy of evolution. (101) [...] The Anand Maye Kosh... is only possessed by a man and not by other creatures in the sense that the man can realise the true meaning of the terms 'bliss and happiness that is eternal and substantial' by the virtue of his attaining higher level of intelligence and his ability to delve into the secrets of the concept of truth itself and then realising that kind of happiness and bliss that is not superficial and which is not limited to enjoyment of the sensual pleasures of the body and the material comforts of the world, but which has a holistic and allinclusive dimension that incorporates the spirit or the soul (Chhawchharia 2017: 101, 102).

Embedded with such immense possibilities and more, like the sixteen kalayein (attractive virtues), nau nidhi (spiritual assets) and aath siddhi (mystical powers) in the fully realized, ideal corporeality, Tulsidas establishes the its indispensability on soul's journey towards salvation. He considers the body to be a temple, Sadhandham (abode of means) and Gyanbhawan (abode of wisdom) which even the deities vie for:

Oh Lord Hari (i.e. Lord Sri Ram)! You had been very kind, benevolent and gracious upon me by giving me (tuma bahuta anugraha kīnhōm-mōhi kṛpā 
kari dīnhōm) a human body which is an instrument by which one can do so many meritorious deeds, and attain liberation, deliverance, emancipation and salvation from the vicious cycle of birth and death (sādhana-dhāma). This body is rare for even the Gods to obtain (bibudha-duralabha tanu) (Chhawchharia 2017: 102).

Like Surdas, Tulsidas also considers human body to be the hetu (direct cause) for the four Purushartha and the means for wise people's spiritual freedom:

This body of yours is an instrument by which you can achieve all sorts of prosperity and fame in this world: it helps you to get the four symbolic rewards of all successful endeavours in one's life that are known as the four fruits of 'Artha' (material prosperity and well-being), 'Dharma' (rewards of being righteous and good in life), 'Kaam' (fulfillment of desires), and 'Moksha' (attainment of emancipation and salvation) (hētu jō phala cārikō) (Chhawchharia 2017: 135).

He takes it to be an agency or a tool for spiritual practice of devotional love to help the devotees to reach the abode of the Absolute Consciousness. It is 'a body which is considered to be a stepping-stone by which all knowledge and wisdom can be accessed, a body which is a means by which a creature can attain enlightenment, wisdom, spiritualism, liberation, deliverance, emancipation and salvation (gyāna-bhavana tanu diyēhu nātha)' (Chhawchharia 2017: 114).

Although Tulsidas is sure of the role of the body and its attributes in facilitating soul's liberation, he is also aware and wary of its volatile nature as well. He calls it a golden pitcher filled with elixir but is equally realizes the possibility of the elixir turning into poison due to diseasing desires, domineering mind and the lazy soul. Therefore, Tulsidas also finds the way of Bhakti the most suitable neutralize the senses, disciplining the mind and awakening the soul to its reality to activate all their corresponding energies to salvage the soul from the world of threefold sufferings. He pictures the body as a village also which needs divine grace to acclimatise devotional songs, discretion and detachment. A man's life, having a beautiful body, name, fame and prosperity will be devoid of bliss like a salt less curry dish, if he doesn't have devotional love for God:

The dirt and countless faults that cling to this Mana can be easily removed without making any effort for it (binu prayāsa) only when the intellect and the sub-conscious mind are washed clean using the water of devotion and affection for the Lord God (Sri Ram) (raghupati-bhagati-bāri-chälita cita), for it is then only that can one see the true nature of the Supreme Lord even without an effort or attempt to do so (binu prayāsa hī süjhai) (Chhawchharia 2017: 124). 
Moreover, despite alluding to the Vedic and the mythological concepts, Tulsidas doesn't propagate the complex scriptural knowledge or physical hardships as prerequisites for devotional affiliation with God to attain spiritual liberation:

He, who is being constantly searched and sought by learned and wise hermits, sages, ascetics (jēhi khōjata muni gyān̄) by undertaking all possible means that have been prescribed for attaining success in this endeavour, such as doing meditation, practicing renunciation, concentration, chanting of Mantras, and doing penances and various other austerities (jōga-birāga, dhyāna-japa-tapa kari)— the same Lord (in his incarnation as Lord Ram) had made friends with lowly creatures such as monkeys, bears and other humble and fickle creatures (bānarabhālu capala pasu pāmara, nātha tahām̉rati mān̄̄) (Chhawchharia 2017: 98).

By referring to these lowlier than human bodies, Tulsidas rightly situates the vital corporeality in the idea of spirituality and validates that to synchronize both in their essential forms no external aid is required; all it takes is a loving meditation on the name of God. That is what God also approves of, as Tulsidas rhetorically inquires:

If you had not sought love, devotion, affection and total surrender (kēvala prēma na cahatē) in place of doing Japa (constant repetition of divine formulas known as 'Mantras' and the Lord's holy Name), religious sacrifices, rituals, penances, austerities, meditation, vows, etc. (jau japa jāga jōga brata barajita)—then why would you have resided in the household of Gopas (cowherds of Vrindavan) instead of in the abode of Gods, or at the hermitages of exalted hermits, sages, ascetics, etc. (tau kata sura munibara bihāya braja, gōpa-gēha basi rahatē)? (Chhawchharia 2017: 97)

And again, instead of subjecting the body to punitive measures, the onus of the self-actualization is transferred to the soul itself; it has to will itself for liberation and involve the powers of the body to establish the communion with God:

Study of the six Shastras and the four Vedas (primary scriptures such as Rig, Yajur, Atharva and Sam is not destined in my destiny (paḍibō paryō na chațī cha mata rigu jajura atharvana sāmakō), and my Mana is filled with fear and recoils when it even hears of such words as 'fastings, penances, religious vows and rituals, austerities, pilgrimage' etc. (brata tīratha tapa suni sahamata). Who would die (i.e. suffer) by practicing their strict discipline, following their rigorous methods, and conforming to their stiff demands (with the threat of punishment and sufferings for failure to do so) (paci marai karai tana chāma kō)? (Chhawchharia 2017: 155) 


\section{Implications and Impact of the New Body Discourse:}

\section{A Bhakti Constructed Body}

Kabir, Surdas and Tulsidas reflect a humanistic perspective in their consideration of human life in an environment which was fraught with dry, abstract intellectualism, rigid faiths, irrelevant and demanding Karmkanda (rituals practiced performed by Brahmins in exchange for money), social exclusions and marginalized existences. They blended the multiple levels of human existence with multiple contexts into the one which provided a human scale understanding of the nature and purpose of having human life. If we compress the range of variously socially/religiously marked bodies in Medieval Indian society, they will emerge like one human body cloud marked with numerous terms which will make it look literally like a body of text. These Bhakti poets, on the contrary, seem to have read the 'text of the body' and found out the basic realities underlying the whole humanity; corporeal or spiritual. They, in fact hewed the man out of the debris of wasteful classifications:

If birth from a Brahman mother makes you Brahman: why did you not come by another way?

If birth from a Turk mother makes you Turk: why were you not circumcised in the womb?

If you milk black and yellow cows together: will you be able to distinguish their milk? (Shah 1917)

These devotee poets/singers or mystics informed the masses' psyche with commentaries on making the best utilisation of the prized human body by completely immersing it in the God, Nirguna or Sagun, to get salvation. James Muttickal thinks that this 'revolutionized the concept of religion' (Muttickal, 2004: 337).

Showing thus the path of direct approach to God through loving devotion, they democratized and localized Divinity and made frequent references from scriptures to prove that all life forms; from lowly to highest have been worthy of God's grace by reciting His name. Such an insightful approach was aimed at the dilution of socially constructed bodies into mere human bodies and weakening the divisive intersectional identities referring to the religion, social class, economic status, gender, literacy, knowledge etc. It did effect the mobilization of the so called lowly bodies upward in what can now be understood as the Maslowian hierarchy of needs. Their idea of Similarity -in the-Dissimilar might be thought of having flowered into the concept of 'Unity in Diversity' that India boasts of. Although most of the Bhakti poets/singers were born in socially and economically deprived section of society, their preaching songs have till now been having people, 
cutting across all segments identify with them. Specifically, their confident emphasis on Bhav (feeling) and Rasa (taste) for Bhakti instead of cognitive intricacies rendered the vision of God attainable to all and sundry. The only eligibility criteria being strong connection of the physical with the spiritual by way of Bhakti; forming the bond of choice with him-as a servant, a beloved, a friend, or a parent. With that personalized and customizable form of Bhakti, they opened the path of moral and spiritual uplifting and salvation for all, including women, untouchables and the fallen.

Their schema of self-realization and enlightenment is echoed by Car Roger's concept of self-actualization which consists of 'the role of therapist is to transform this (incongruent) view to a congruent one, both by adjusting person's perception of self-image and self-worth as well as making an ideal self' more realistic' (Journalpsyche.org 2015). These mystics were such psychological therapists whose songs/teachings enshrine within them the idea of performative therapy in its rudimentary form, and they still inform lives in that capacity. Kabir says:

O Pandit, see and ponder in your heart, who is male and who is female.

He who silently pervades, speaks in everybody: his ways are wonderful:

How can one call upon thd name of Him who has no name, no colour, no form?

Consider, O Pandit, it appears as a tree; half is in-dwelt by male and half by female (Shah 1917)

Both Surdas and Tulsidas refer to various mythological characters like Vidur: a maid's son; Pingla: a prostitute; Sabari: a tribal woman; Ajamil: a sinning king; kubja: a hunch backed maid; draupadi: a dishonored queen; Vishwamitra: a robber turned sage and so on, to emphasize that the type, shape, status or appearance of a body has never been a hindrance in getting God's grace and acceptance.

Moreover, it is interesting to see how the human body, with all its natural affiliations with and inclinations towards the material objects is projected by them as a double-edged sword: dangerous if held by the blade; beneficent when held firmly by the hilt. These poets/singers reflect upon the Illusion and ignorance mediated condemned interaction of body and soul that results in the proliferation of imbalanced attributes born fruits of actions (karma). They have proposed working towards moulding this body, with all the powers of mind, words and actions, into a new one, with only one identification mark, a liberating one: a body and soul mediated Bhakt body. Such a bold proposition ensued a kind of identity negotiation which led to major shifts in the bodily identities from ascribed and inscribed bodies to avowed or subscribed bodies as Bhakt. Specifically, this idea of a potent Bhakt body hit hard at the vanity of the condescending self imposed body identity, the excruciatingly fashioned forged body identity and the suffocating forced 
identities that were refereeing as well regulating the physical and spiritual choices in human life. Their followers molted such artificial integuments off their bodies at a large scale to attain the Empowered corporeality of a Bhakt and by being in an intense emotional communion with God, fully realize their potential and purpose on earth.

\section{Conclusion: Substantial and Substantive Corporeality}

Having traversed through the discursive spaces fashioned by Kabir, Surdas and Tulsidas regarding human corporeality as a relational concept and its insinuated centrality in human life which is surrounded by a web of contexts, the discussion can be rounded off with an observation regarding the contemporary relevance and possibilities of their reflections.

Carl Rogers notices that 'the curious paradox is that when I accept myself just as I am, then I can change' (quoted in Journalpsyche.org 2015). This is what has been affected through the ideas of these mystic poets: the powerless entity of the binary power relationships in Gramscian sense learnt self-acceptance and have still been referring to these poets to enhance the self worth and self image. These poets, along with the other of their kind serve even today a point of reference to have an insight of the untapped pool of talent they have. A song of Surdas sung by a prostitute is said to have helped him achieve transcendence.

Tulsidas has used this ploy of criticizing himself to indirectly warn others about the way they are wasting their lives in false pursuit of happiness and joy. True goal of human life is to attain eternal happiness and bliss, of obtaining deliverance of the soul and finding final emancipation and salvation. It is to be an honest effort addressed to one's own self, and not done to please others or deceive the world (Chhawchharia 2017).

The centrality of the corporeal body comes to fore in their efforts to galvanize the masses to move from balancing the three attributes of Satva, Rajas and Tamas with an aim of reaching the pure Satvik state, train the mind, use the discerning power and thus improve the holistic quality of life in this lifetime only: 'Parted from God they offered arti. O Rama, grant them the vision. At death Thou wilt grant the vision: but what profits this?' (Shah 1917)

This schema of physical, psychological, mental and spiritual well being will provide answers to those who are apprehensive of the idea of Bhakti for an abstract Divinity or an image or a statue. Human beings are instinctively motivated to strive for a better and higher than the present condition. We have our individual or collective ideal or vision of an ultimately blissful life of contentment. For these mystic poets, that ideal or vision comes in the form of a Nirgun or Sagun divinity and the means to realize that vision is to 
be in constant communion with it. What is actually worthy of gleaning from their discourses is the idea of timely adopted, corrective and balanced approach in life, being single-minded and whole-hearted focus on the ideal, letting the body experience/taste the progressive process of enlightenment and realizing the vision in one's lifetime only. And it is best done before the corporeal being starts deteriorating and is rendered incapable of acting upon the inner motivations.

It is a well known adage that a person's company defines/informs his personality. These poets/singers provide a formula for a quality life. The need to safeguard our bodies from the hypocritical and misleading people and relationships is repeatedly stressed upon by Surdas and Tulsidas when they project every worldly relation to be fickle and temporary and warn against being excessively indulgent in them. Kabir shows more conviction in his response to such hypocrisy: 'I thought you to be of the race of the swan, therefore I kept by your side. Had I known you were kin to the crane, I had never let you touch my body' (Shah 1917).

With such a campaign for improving the quality of life, the skills of life management are embedded within their discursive space where mind management has specifically been underlined. In the wake the never ceasing explorations and inventions in the field of cognitive sciences, especially with the increasingly complex conditions of life in a fast changing environment, the enhanced intelligence, the massive data on behavioral and cognitive patterns and the immense scope of Artificial Intelligence, these Bhakti poets' ideas on mind become futuristic revelations and call our attention for attending upon the new existential issues: 'The body is a ship and mind a crow: millions of leagues it flies. Sometimes it sinks in the fathomless river of doubt; sometimes it enters heaven' (Shah: 1917).

Tulsidas also holds the corrupted, perverted and wicked mind that turns a wish-fulfilling creeper (Kalpa lata) like body into a poisonous fruit of suffering and miseries.

As for such performative discourses practically effecting systematic, institutionalized changes, it should be noted that Sikhism, the latest and most reformed religion on the Indian landscape is also considered to be the outcome of the Bhakti movement informed by Sufi traditions of late Medieval India. Its tenets show the influence of these poets, mostly Kabir. Under their influence Sikhism became the only religion of India which does not principally observe the demeaning or arrogant identifications of body and the entailing rituals and allows menstruating women inside their places of worship; both public and private. There are many direct or indirect ways through which the practical philosophy of these poets informs the thinking and workings of people. The idea of secularism, the modern discourses of body, identity poetics, the deconstructionist view etc find resonance within 
the Bhakti tradition. They have in fact turned the contemporary body politics into body poetics and Kabir, the most straightforward of the three mystic analysed here, is very clear in his revisionist agenda:

Vain-glorious of authority you make me to be circumcised: never will I endure it, brother.

If it is God that makes thee to be circumcised, why came not this cutting of itself [...] By putting on the sacred thread one becomes a Brahman. What has thou given to women to wear? She from birth is but a Sudra, why dost thou eat the food she brings, O Pande (Shah 2017).

However, the rise of various related Sampradaya (Spiritual systems) in the aftermath of Bhakti movement like Kabir panth, Ashthchap though helps dissemination of their ideas keep going, yet by specifically marking their bodies to show their affiliation goes against the teachings of their Guru (teacher). The teachers rose against the intentionally exclusivist attitudes; the disciples tend to have turned themselves into the same situation. Nevertheless, going by the essential spirit of their teaching, they are seen to be having the potential to inform our understanding of our own duty towards ourselves, our society and our environment, too. When we are still universally struggling with new forms of multilayered, bio-psychosocial, economical, religious, political and technological feudalism, it can possibly help to have such discourse as reference points in our debates on the existential issues and the dynamics of discord. As striving towards making the corporeal body perfected into a Bhakt body empowers a person with a promising mission because as Tulsidas affirms and echoes the belief of other Bhakti poets: 'A person who attains this eclectic and transcendental state of existence marked by eternal blissfulness, tranquillity and equanimity (jākī dasā aisī bha'ī), is the one who can purify the whole world by showing it the correct path that leads to contentedness and happiness (trailōka-pāvana sō sadā)' (Chhawchharia 2017: 136).

\section{References}

'Hermeneutical phenomenology.' http://www.phenomenologyonline.com/inquiry/orientations-in-phenomenology/hermeneuticalphenomenology/. [Accessed on Dec. 11, 2018]

Chhawchharia AK (2017) Vinaya-Patrikā: A Book of Supplication E True Love for God. See https://tulsidasrambooks.weebly.com/uploads/2/1/7/4/21746472/vinai_patrika_of_goswami_tulsidas.pdf. [Accessed on Nov. 26, 2018]

Hodrege B (2015) Bhakti and Embodiment: Fashioning Divine Bodies and Devotional Bodies in Krsna Bhakti. London: Routledge. 
Holdrege B (1998) Body Connections: Hindu Discourses of the Body and the Study of Religion. International Journal of Hindu Studies 2(3): 341-386. https://www.worldcat.org/title/bhakti-and-embodiment-fashioning-divinebodies-and-devotional-bodies-in-krsna-bhakti/oclc/918941177/viewport. [Accessed on December 5, 2015]

Jayaram V (2018) Atman, The Eternal Soul or Self in Hinduism. https://www.hinduwebsite.com/beliefinsoul.asp. [Accessed on November 21, 2018]

Journalpsyche.org (2015) Revisiting Carl Rogers Theory of Personality. Journal Psyche. http://journalpsyche.org/revisiting-carl-rogers-theory-ofpersonality/. [Accessed on Nov. 17, 2015]

Khanna M (2007) Cultural History of Medieval India. New Delhi: Social Science Press.

Medieval India: Bhakti Movement. http://knowindia.gov.in/culture-andheritage/medieval-history/bhakti-movement.php. [Accessed on March 13, 2019]

Monier-Williams M (2008) Sanskrit-English Dictionary. https://www.sanskritlexicon.uni-koeln.de/monier/. [Accessed on Nov. 21, 2018]

Muttickal J (2004) Mystic Poets of Bhakti Movement. Journal of Dharma: Dharmaram Journal of Religions and Philosophies 29(3): 337-350.

Shah A (1917) Bijak of Kabir. Retrieved from https://archive.org/stream/bijakofkabirtran00kabiuoft/bijakofkabirtran00kabiuoft_djvu.txt.

Singh S (2016) Sur-Vinay-Patrika. Gorakhpur: Geeta Press. Retrieved from https://archive.org/details/in.ernet.dli.2015.474175/page/n101. 